\title{
A win in protection against ischemia-reperfusion injury?
}

\author{
Tyson A. Fricke, MBBS, BMedSci, ${ }^{a, b, c}$ and Igor E. Konstantinov, MD, PhD, FRACS ${ }^{\mathrm{a}, \mathrm{b}, \mathrm{c}, \mathrm{d}}$
}

\footnotetext{
From the a Department of Cardiac Surgery, The Royal Children's Hospital, Melbourne, Victoria, Australia; ${ }^{\mathrm{b}}$ Department of Paediatrics, The University of Melbourne, Melbourne, Victoria, Australia; 'Murdoch Children's Research Institute, Melbourne, Victoria, Australia; and dMelbourne Children's Centre for Cardiovascular Genomics and Regenerative Medicine, Melbourne, Victoria, Australia.

Disclosures: Authors have nothing to disclose with regard to commercial support.

Received for publication July 27, 2018; accepted for publication July 27, 2018; available ahead of print Aug 31, 2018.

Address for reprints: Igor E. Konstantinov, MD, PhD, FRACS, Royal Children's Hospital, Flemington Rd, Parkville, Victoria 3052, Australia (E-mail: igor.konstantinov@ rch.org.au).

J Thorac Cardiovasc Surg 2019;157:504-5

$0022-5223 / \$ 36.00$

Crown Copyright @ 2018 Published by Elsevier Inc. on behalf of The American Association for Thoracic Surgery https://doi.org/10.1016/j.jtcvs.2018.07.083
}

The human race has used plant-derived cannabinoids, most commonly referred to today as marijuana, for more than 6000 years. ${ }^{1}$ The first record of the medical application of the strong anti-inflammatory effect of cannabinoids comes from the world's oldest pharmacopoeia, which was found in China. ${ }^{1}$ During the early 1990s, the endogenous ligand for cannabinoid receptors, anandamide, was identified. ${ }^{2}$ The name of the naturally occurring fatty acid derivative anandamide comes from the Sanskrit word ananda, which means bliss, delight, or joy, a description that very well reflects its strong anti-inflammatory, pain-relieving properties. ${ }^{2}$ Recently, the therapeutic anti-inflammatory effect of synthetic fatty acid derivative WIN55212-2,

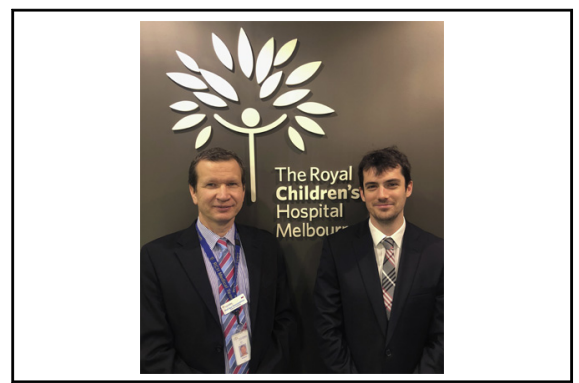

Igor E. Konstantinov, MD, PhD, FRACS, and Tyson A. Fricke, MBBS, BMedSci

\section{Central Message}

Synthetic cannabinoid agonists may provide protection against ischemia reperfusion injury.

See Article page 494 a nonselective cannabinoid agonist of cannabinoid 1 (CB1) and cannabinoid 2 (CB2) receptors, has been explored. These cannabinoid receptors belong to the G-protein coupled receptor family and play a key role in downstream intracellular regulation of apoptosis and

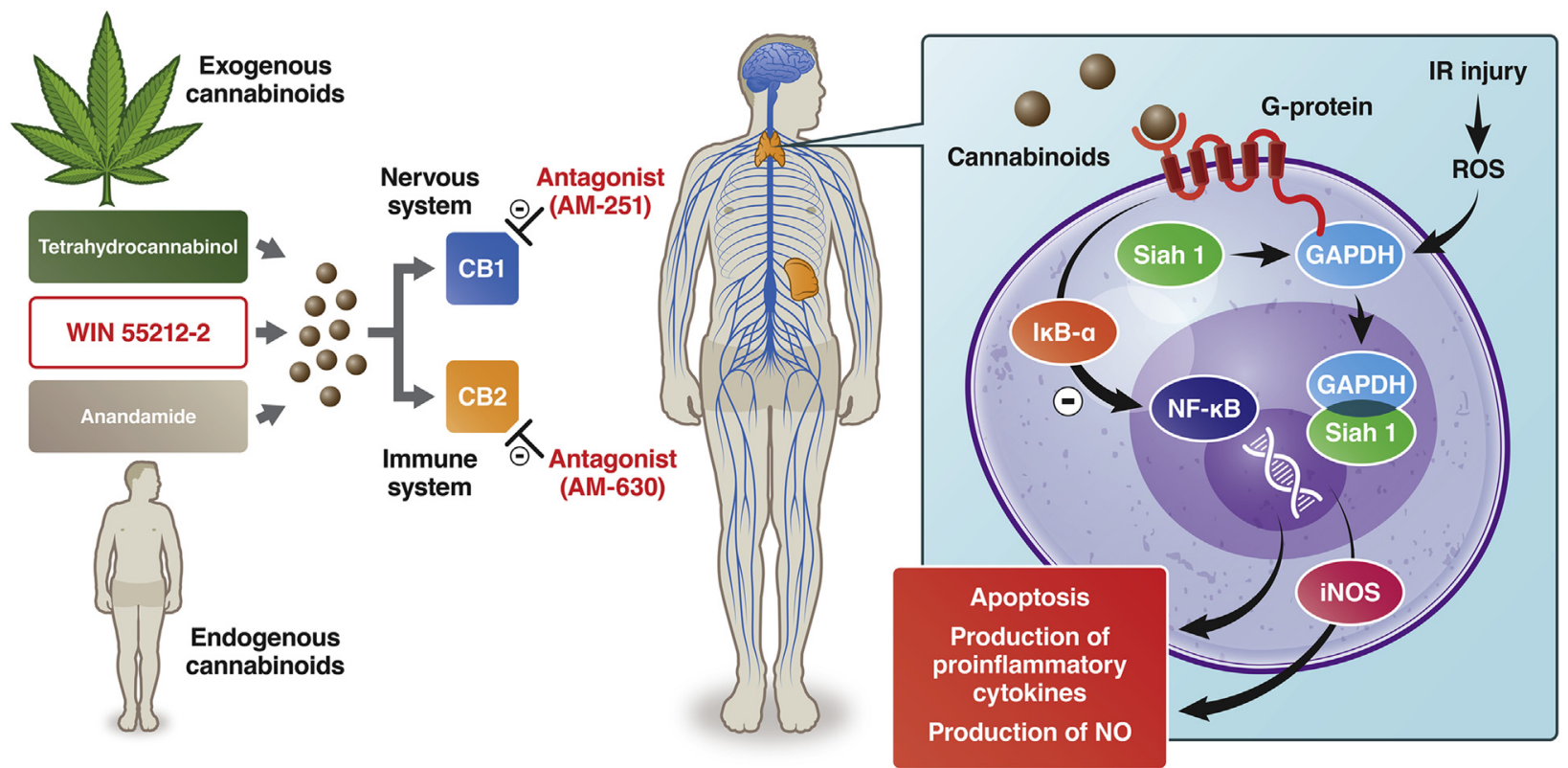

FIGURE 1. Pathways of cannabinoid receptor-mediated protection against ischemia-reperfusion (IR) injury. Cannabinoid receptor ligand (WIN55212-2) binding to cannabinoid receptors may reduce apoptosis and decrease proinflammatory cytokines and nitric oxide (NO) by increasing cytosolic inhibitory $\mathrm{kB} \alpha$, thus decreasing nuclear translocation of nuclear factor-kB $(N F-k B)$ and decreasing nuclear translocation of the glyceraldehyde-3-phosphate dehydrogenase $(G A P D H) / S i a h 1$ complex. $C B 1$, Cannabinoid receptor 1; $C B 2$, cannabinoid receptor 2; $I k B \alpha$, inhibitory $\mathrm{kB} \alpha$; iNOS, inducible nitric oxide synthase; ROS, reactive oxygen species. 
inflammation (Figure 1). CB1 receptors are located mostly in the central nervous system. In contrast, $\mathrm{CB} 2$ receptors are expressed mostly in the immune system, including the thymus, spleen, lymphatic nodes, and circulating leukocytes, where they mediate cytokine release. ${ }^{3}$ Some CB2 receptors are also present in nervous system tissue. ${ }^{4}$ In rat models, WIN55212-2 protected against ischemiareperfusion (IR) injury in brain ${ }^{5}$ and heart ${ }^{6}$ tissue.

A fascinating article by Huo and colleagues ${ }^{7}$ focuses on the protective effect of WIN55212-2 against IR injury. The authors used WIN55212-2 in a rat model of spinal cord IR injury and demonstrated that WIN55212-2 decreased nuclear translocation of both glyceraldehyde-3-phosphate dehydrogenase (GAPDH) and nuclear factor-kB (NF-kB).

The ubiquitous cytoplasmic enzyme GAPDH is an important mediator in apoptosis. It appears that GAPDH binds with Siah1 in response to IR injury followed by nuclear translocation of the GAPDH/Siah1 complex that, in turn, is associated with increased apoptosis. ${ }^{8}$ Huo and colleagues $^{7}$ speculated that the inhibitory action of WIN55212-2 on the GAPDH/Siah1 cascade might be due to the suppression of nitric oxide production, given the observation that the protein expression of inducible nitric oxide synthase in the spinal cord of IR injury was reduced in the presence of WIN55212-2. They also demonstrated that WIN55212-2 decreased nuclear translocation of NF$\mathrm{kB}$ and increased cytosolic inhibitory $\mathrm{kB} \alpha$, a marker of NF-kB signaling activation. ${ }^{7} \mathrm{NF}-\mathrm{kB}$ is a key mediator of inflammation in IR injury. ${ }^{9,10}$

Huo and colleagues ${ }^{7}$ found that WIN55212-2 reduced the production of proinflammatory cytokines and reduced apoptosis of spinal cord cells, resulting in improved neurologic outcome and spinal neuron survival. The effects of WIN55212-2 were reversed by a CB2 receptor antagonist (AM630), but not by a CB1 antagonist (AM251), strengthening the evidence for a key role of the CB2 receptormediated pathway. This elegant study is a significant step in our understanding of cannabinoid-induced protection and may lead to important clinical translation in surgery. The ancient saga of cannabinoid receptors continues!

\section{References}

1. Hand A, Blake A, Kerrigan P, Samuel P, Friedberg J. History of medical cannabis. J Pain Manag Med. 2016;9:387.

2. Devane WA, Hanus L, Breuer A, Pertwee RG, Stevenson LA, Griffin G, et al. Isolation and structure of a brain constituent that binds to the cannabinoid receptor. Science. 1992;258:1946.

3. Galiègue S, Mary S, Marchand J, Dussossoy D, Carrière D, Carayon P, et al. Expression of central and peripheral cannabinoid receptors in human immune tissues and leukocyte subpopulations. Eur J Biochem. 1995;232:54-61.

4. Kendall DA, Yudowski GA. Cannabinoid receptors in the central nervous system: their signaling and roles in disease. Front Cell Neurosci. 2016;10:294.

5. Fernández-López D, Pradillo JM, García-Yébenes I, Martínez-Orgado JA, Moro MA, Lizasoain I. The cannabinoid WIN55212-2 promotes neural repair after neonatal hypoxia-ischemia. Stroke. 2010;41:2956-64.

6. González C, Herradón E, Abalo R, Vera G, Pérez-Nievas BG, Leza Juan C, et al. Cannabinoid/agonist WIN 55,212-2 reduces cardiac ischaemia-reperfusion injury in Zucker diabetic fatty rats: role of CB2 receptors and iNOS/eNOS. Diabetes Metab Res Rev. 2011;27:331-40.

7. Huo J, Ma R, Chai X, Liang H-J, Jiang P, Zhu X-1, et al. Inhibiting a spinal cord signaling pathway protects against ischemia injury in rats. J Thorac Cardiovasc Surg. 2019;157:494-503.e1.

8. Hara MR, Cascio MB, Sawa A. GAPDH as a sensor of NO stress. Biochim Biophys Acta Mol Basis Dis. 2006;1762:502-9.

9. Tak PP, Firestein GS. NF- $\kappa$ B: a key role in inflammatory diseases. J Clin Investig. 2001;107:7-11.

10. Ridder DA, Schwaninger M. NF- $\kappa \mathrm{B}$ signaling in cerebral ischemia. Neuroscience. 2009;158:995-1006. 